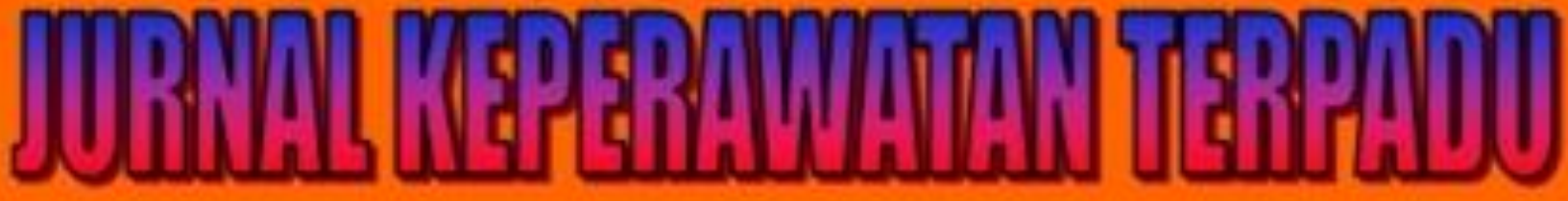

\section{Integrated Nursing Journal}

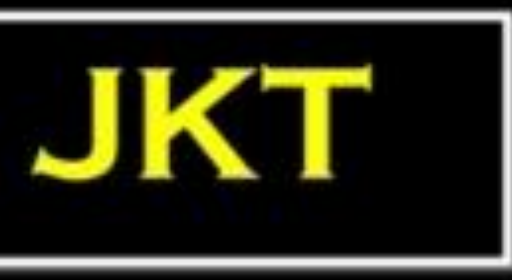

\section{p-ISSN: 2406-9698 (Print) e-ISSN: 2685-0710 (Online)}

\section{Vol. 2 No. 1 April 2020}

\section{KEMENTERIAN KESEHATAN RI}

\section{POLTEKKES MATARAM JURUSAN KEPERAWATAN}

Jalan Kesehatan V/10 Mataram NTB - http://jkt.poltekkes-mataram.ac.id 


\section{Vol. 2 No. 1 April 2020}

\section{Editorial Team}

\section{Editor-in-Chief}

Moh. Arip, Jurusan Keperawatan Poltekkes Kemenkes Mataram, Indonesia

\section{Editorial Board}

1. Mr. Frans Judea Samosir, Universitas Prima Indonesia, Indonesia

2. Baiq Kirana Kitna, Jurusan Keperawatan, Poltekkes Kemenkes Mataram, Indonesia

3. Irwan Budiana, Jurusan Keperawatan, Poltekkes Kemenkes Kupang, Indonesia

4. dr. Baskoro Tri Laksono, RS. Biomedika Mataram, Indonesia

5. Sitti Rusdianah, Jurusan Keperawatan, Poltekkes Kemenkes Mataram, Indonesia

6. Mira Utami Ningsih, Jurusan Keperawatan, Poltekkes Kemenkes Mataram, Indonesia

\section{Alamat Redaksi:}

Jurusan Keperawatan Mataram Poltekkes Kemenkes Mataram Kampus B

Jl. Kesehatan V No.10 Pajang Timur-Mataram NTB-Indonesia, 83127

Telepon: +62 370-621383

Fax: +62 370-631160

Email: jurnalkeperawatanterpadu2019@gmail.com

Laman: http://jkt.poltekkes-mataram.ac.id/index.php/home/index 


\section{Vol. 2, No. 1, April 2020}

\section{DAFTAR ISI}

Pengaruh Self Hypnosis Terhadap Respon Cemas Mahasiswa

Pada Ujian Tahap Akhir Program Di STIKes Buana Husada Ponorogo

Yudha Anggit Jiwantoro, Afifa Ika Kridawati, Danies Tunjung Pratiwi

Efektifitas Tepid Water Sponge Terhadap Penurunan Suhu Tubuh Pada Anak Dengan Masalah Keperawatan Hipertermia: Studi Kasus

Emy Mulyani, Nur Eni Lestari

Perilaku Pencegahan Penyakit Tidak Menular Pada Remaja Ambon

Hamdan Hariawan, Martini Tidore, Greeny Z. Rahakbau

Pengetahuan dan Sikap Perawat Berhubungan dengan Pelaksanaan Patient

Safety

Elisa Sulistia Fitri, Kusnanto, Herdina Maryanti

Efektivitas Art Therapy terhadap Pengetahuan dan Praktik Pemeliharaan Kesehatan Gigi pada Anak Usia Prasekolah

Linda Widyarani, Wiwi Kustio Priliana, Cecilya Kustanti

Konsep Diri Remaja Yang Mengalami Bullying

Puji Lestari, Liyanovitasari

Pengaruh Senam Tai Chi Terhadap Peningkatan Kualitas Tidur Lansia Di Balai Sosial Lanjut Usia Mandalika

Fathaillah Liestanto, Dina Fitriana

Hubungan Komunikasi Terapeutik Perawat Dengan Tingkat Kecemasan

Pasien Hemodialisa Di RSUD Dr Harjono Ponorogo

Ervan Nur Cholis, Rumpiati Rumpiati, Ike Sureni

Upaya Mengatasi Nyeri Post Op Sectio Cesaria Melalui Foot Massage Therapy Diruang Nifas RSUD Kota Mataram

Masadah, Cembun, Ridawati Sulaeman

Peningkatan Pemberdayaan Keluarga Melalui PINKESGA (Paket Informasi Keluarga) Kehamilan Dalam Mengambil Keputusan Merawat Ibu Hamil Mardiatun, Dewi Purnamawati, Ely Mawaddah
Page

$1-6$

Page

$7-14$

Page

$15-21$

Page

22-28

Page

29-39

Page

40-46

Page

$47-53$

Page

54-63

Page

$64-70$

Page

$70-78$ 


\title{
Konsep Diri Remaja Yang Mengalami Bullying
}

\author{
Puji Lestari $^{1}$, Liyanovitasari ${ }^{2}$ \\ ${ }^{1,2}$ Program Studi S1 Keperawatan Universitas Ngudi Waluyo
}

\begin{abstract}
Abstrak
Konsep diri terdiri dari semua nilai-nilai, keyakinan dan ide-ide yang berkontribusi terhadap pengetahuan diri dan mempengaruhi hubungan seseorang dengan orang lain. Bullying dapat menjadikan konsep diri remaja terganggu. Tujuan penelitian untuk mengetahui konsep diri remaja yang mengalami bullying. Penelitian ini merupakan penelitian kuantitatif dengan pendekatan survey deskriptif. Sampel 88 remaja yang pernah mengalami bullying. Alat ukur konsep diri dengan Tennessee Self Concept Scale (TSCS). Hasil penelitian menunjukkan remaja yang memiliki konsep diri yang positif sebanyak 45 responden $(51,1 \%)$, sedangkan remaja yang memiliki konsep diri negatif sebanyak 43 $(48,9 \%)$. Diharapkan adanya upaya dari masyarakat dan institusi pendidikan untuk mengatasi perilaku bullying yang dapat berdampak pada konsep diri remaja.
\end{abstract}

Kata kunci $\quad$ : Konsep diri; remaja; bullying

\begin{abstract}
The self concept consists of all values, beliefs and ideas that contribute to self-knowledge and affect one's relationship with others. Bullying can make adolescent self-concepts disrupted. Research objectives to know the self concept of adolescent who have bullying. This research is a quantitative research using descriptive survey approach. Sample 88 adolescent who has experienced bulliying. Self-concept measuring instrument with Tennessee Self Concept Scale (TSCS). The results showed adolescents who had a positive self-concept of 45 respondents $(51.1 \%)$, while adolescents who had a negative selfconcept of $43(48.9 \%)$. It is expected that the efforts of the Community and educational institutions to overcome bullying behaviour can impact the self concept of adolescent.
\end{abstract}

Keywords: self concept; adolescent; bullying

\section{PENDAHULUAN}

Masa remaja adalah masa di antara usia 11 dan 20 tahun (adolescence) merupakan masa dimana terjadi transisi masa kanak-kanak menuju dewasa. Perubahan yang terjadi pada remaja baik secara fisik, psikis, maupun sosial akan mempengaruhi remaja dengan pembentukan konsep dirinya (Potter \& Perry, 2010). Perkembangan konsep diri individu di mulai dari usia muda dan akan terus berlanjut hingga sepanjang masa kehidupan, pada usia remaja terjadi perkembangan identitas apabila pada masa ini seseorang individu gagal melewati akan menyebabkan citra diri, gangguan perkembangan diri, harga diri rendah, 
perubahan identitas bahkan kebingungan peran yang berujung pada konsep diri yang negatif (Apriliyanti, Mudjiran \& Ridha, 2016).

Konsep diri adalah konseptualisasi individu terhadap dirinya sendiri yang merupakan perasaan subjektif individu dan kombinasi yang kompleks dari pemikiran yang di sadari/tidak di sadari, sikap dan presepsi. Konsep diri secara langsung mempengaruhi harga diri dan perasaan seseorang tentang harga diri nya sendiri.Konsep diri merupakan bagian yang paling kompleks dari semua kualitas manusia. Konsep diri terdiri dari semua nilai-nilai, keyakinan, dan ide-ide yang berkontribusi terhadap pengetahuan diri dan mempengaruhi hubungan seseorang dengan orang lain, termasuk persepsi seseorang tentang karakteristik dan kemampuan pribadi serta tujuan dan cita-cita seseorang (Potter \& Perry, 2010).

Konsep diri terbentuk dari pengalaman internal seseorang, hubungan dengan orang lain dan interaksi dengan dunia luar. Adaptasi yang baik pada individu untuk membentuk konsep diri yang positif apabila individu gagal dalam beradaptasi dan mempengaruhi seluruh aspek konsep diri yang akan menyebabkan terbentuknya konsep diri yang negatif (Muawanah, 2012).

Biasanya kelompok remaja seringkali mengucilkan remaja lain dengan memandang hal-hal yang berbeda dari anggota remajanya seperti warna kulit, latar belakang, aspek berpakaian, gesture,dan selera. Seringkali kita lihat banyak remaja yang mengalami penolakan saat ingin berinteraksi bahkan bergabung dengan remaja lain, penolakan ini bisa kita sebut dengan bullying (Apriliyanti et al., 2016).

Bullying adalah bagian dari tindakan agresi yang di lakukan berulangkali oleh seseorang/anak yang lebih kuat terhadap anak yang lebih lemah scara psikir dan fisik. (Sufriani \& Sari, 2017). Bentuk-bentuk bullying di bagi menjadi 3 katagori yaitu bullying fisik, bullying verbal, dan bullying mental/psikologis. Korban yang sering menerima tindakan bullying seringkali mengalami tidak percaya diri, tidak nyaman berada di sekolah, takut, rendah diri, penurunan prestasi akademik, sulit berkonsentrasi bahkan sempat berkeinginan untuk bunuh diri (Priyatna, 2010).

Hasil penelitian yang pernah di lakukan oleh Rompas (2018) terdapat hubungan antara bullying dengan kepercayan diri pada remaja di SMP Negeri 10 Manado. Hasil studi pendahuluan yang di lakukan dengan wawancara 10 siswa, di siswa mengatakan sering di panggil temannya tidak dengan nama sendiri melainkan dengan nama orang tua, ada yang memiliki tubuh kurang tinggi dan gemuk sering jadi bahan tertawaan teman- 
temannya, ada yang pernah di todong uang jajan. Reaksi siswa yang pernah mengalami bullying tersebut ada yang menjadi pendiam, ada yang jengkel dan ada yang merasa tubuhnya tidak menarik lagi. Hal tersebut selaras dengan penelitian Zakiyah, Humaedi, \& Santoso (2017) menjelaskan bahwa perilaku bullying memiliki dampak dalam masalah kesehatan baik secara fisik (seperti sakit kepala, sakit perut dan ketegangan otot, rasa tidak aman saat berada di lingkungan sekolah, dan penurunan semangat belajar dan prestasi akademis) maupun mental (seperti depresi, kegelisahan dan masalah tidur yang mungkin akan terbawa hingga dewasa). Penelitian ini bertujuan untuk mengetahui konsep diri remaja yang pernah mengalami tindakan bullying

\section{METODOLOGI PENELITIAN}

Penelitian ini merupakan penelitian kuantitatif dengan pendekatan survei deskriptif. Sampel 88 remaja yang pernah mengalami bullying di SMPN 4 Ungaran Kabupaten Semarang yang diambil secara proportionate random sampling. Sampel terdiri dari kelas 7 sebanyak 31 siswa, kelas 8 sebanyak 32 siswa dan kelas 9 sebanyak 25 siswa. Alat pengumpulan data terdiri dari kuesioner untuk mengidentifikasi karakteristik responden (umur \& jenis kelamin) serta alat ukur konsep diri dengan Tennessee Self Concept Scale (TSCS) yang terdiri dari 100 pertanyaan. Konsep Diri kemudian dikategorikan menjadi dua yaitu konsep diri positif jika skor >mean $(362,31)$, dan konsep diri positif jika skor < mean $(362,31)$. Pengambilan data dilakukan pada bulan Oktober 2019 dengan lama pengambilan data selama 2 hari.

\section{HASIL PENELITIAN}

Tabel 1. Karakteristik Responden berdasarkan usia $(\mathbf{n}=\mathbf{8 8})$

\begin{tabular}{lllllll}
\hline Variabel & Mean & Median & Modus & SD & Min & Max \\
\hline Umur & 13,28 & 13,00 & 13 & 0,970 & 11 & 16 \\
\hline
\end{tabular}

Pada Tabel 1. Terlihat bahwa umur responden rata rata adalah 13 tahun 
Tabel 2. Karakteristik Responden berdasarkan jenis kelamin $(n=88)$

\begin{tabular}{lcc}
\hline \multicolumn{1}{c}{ Jenis Kelamin } & Frekuensi & Persentase (\%) \\
\hline Laki - laki & 46 & 52,3 \\
Perempuan & 42 & 47,7 \\
\hline Total & $\mathbf{8 8}$ & $\mathbf{1 0 0}$ \\
\hline
\end{tabular}

Tabel 2. menunjukkan bahwa responden pada penelitian ini adalah sebagian besar berjenis kelamin laki-laki yaitu sebanyak $46(52,3 \%)$.

Tabel 3. Konsep Diri Remaja yang pernah mengalami Bullying

\begin{tabular}{lcc}
\hline \multicolumn{1}{c}{ Konsep diri } & Frekuensi & Persentase (\%) \\
\hline Negatif & 43 & 48,9 \\
Positif & 45 & 51,1 \\
\hline Total & $\mathbf{8 8}$ & $\mathbf{1 0 0}$ \\
\hline
\end{tabular}

Tabel 3. menunjukkan bahwa sebagian besar remaja yang memiliki konsep diri negatif sebanyak 43 responden $(48,9 \%)$ dan remaja yang memiliki konsep diri positif sebanyak 45 responden $(51,1 \%)$.

\section{PEMBAHASAN}

Berdasarkan hasil penelitian terhadap 88 responden didapatkan data bahwa semua responden pernah mengalami tindakan bullying, dan yang paling sering adalah bullying verbal dan psikologi antara lain dipanggil bukan namanya (dengan sebutan lain), dijauhi, diolok olok dengan kekurangannya. Konsep Diri pada responden didapatkan bahwa jumlah yang mempunyai konsep diri positif dan negatif hampir seimbang, yaitu yang memiliki konsep diri positif sebanyak $45(51,1 \%)$ dan yang memiliki konsep diri negatif sebanyak $43(48,9 \%)$.

Konsep diri dapat di lihat dari berbagai aspek yang meliputi identitas diri, citra tubuh, ideal diri, harga diri dan peran diri. Identitas diri adalah kesadaran akan diri sendiri yang bersumber dari observasi dan penilaian dari semua aspek konsep diri sebagai suatu kesatuan yang utuh. Seseorang yang mempunyai perasaan identitas diri yang kuat akan memandang dirinya berbeda dengan orang lain, unik dan tidak ada duanya. Kemandirian timbul dari perasaan yang berharga, kemampuan dan penguasaan diri seseorang yang 
mandiri dapat mengatur dan menerima dirinya (Sumantri, 2011). Citra tubuh merupakan kumpulan sikap individu yang di sadari dan tidak di sadari terhadap tubuhnya, termasuk persepsi serta perasaan masa lalu dan sekarang tentang ukuran, fungsi, penampilan, dan potensi. Citra tubuh di modifikasi secara berkesinambungan dengan persepsi dan pengalaman baru (Stuart, 2013). Peran diri adalah pola perilaku, sikap nilai dan aspirasi yang di harapkan individu berdasarkan posisinya di masyarakat. Setiap individu di sibukkan oleh berbagai macam peran yang terkait dengan posisinya pada setiap saat. (Sunaryo,2013). Harga diri yang merupakan perasaan yang berasal dari penerimaan diri sendiri tanpa syarat walaupun melakukan kesalahan, kekalahan, kegagalan dan tetap merasa sebagai orang yang penting dan beharga. Ideal diri adalah presepsi individu tentang perilakunya di sesuaikan dengan standart pribadi yang terkait dengan cita - cita, harapan, keinginan, tipe orang yang di idam-idamkan dan nilai yang ingin di capai (Stuart 2013).

Berdasarkan jawaban responden yang memiliki konsep diri positif antara lain 71,6\% mengetahui keadaan yang ada pada dirinya, $72,7 \%$ menerima dan menyadari bahwa dirinya masih kurang rajin dalam beribadah, 70,5\% menyadari bahwa kedaan sosial dalam diri responden sangat baik karena mereka suka berteman, 65,9\% memiliki penerimaan yang baik dalam suatu keluarga, 31, $8 \%$, responden sudah bisa menilai dan memahami postur dan bentuk tubuh nya sendiri sebagaimana adanya, 34,1\% merasa puas dengan keadaan yang ada pada dirinya jadi dapat di simpulkan bahwa responden memiliki penerimaan diri dengan cukup baik.

Konsep diri bagi remaja akan menentukan sikap dan perilaku remaja. Dalam pengembangan konsep diri remaja ada hal yang tidak boleh di abaikan yaitu proses internalisasi nilai - nilai yang dapat membentuk konsep diri pada remaja yang positif dan kearah yang dapat mendewasakan diri. Seseorang yang mempunyai konsep diri yang positif cenderung mendorong sikap optimis dan percaya diri yang kuat untuk menghadapi situasi apa saja di luar diri individu, namun sebaliknya konsep diri negatif akan menimbulkan rasa tidak percaya diri dan ini dapat mengundang kompensasi dengan bertindak agresif kepada obyek-obyek yang ada di sekitar diri individu yang bersangkutan, yang di landasi oleh rasa ketidak berdayaan yang berlebihan.

Pada penelitian ini juga didapatkan bahwa sebanyak 48,9 \% yang pernah mengalami bullying memiliki konsep diri negatif. Hal ini bisa disebabkan karena teman sebaya mempengaruhi pola kepribadian remaja dalam dua cara. Pertama konsep diri remaja merupakan cerminan dari anggapan tentang konsep teman-teman tentang dirinya. Kedua, 
ia berada dalam tekanan untuk mengembangkan ciri-ciri kepribadian yang di akui kelompok (Sarwono, 2013). Salah satu faktor yang mempengaruhi konsep diri adalah tingkat perkembangan dan kematangan, dimana konsep diri terbentuk melalui proses belajar sejak masa pertumbuhan manusia dari kecil hingga dewasa (Widiarti, 2017).

Semua responden dalam penelitian ini pernah mengalami bullying, namun tidak semua mempunyai konsep diri yang negatif. Hal ini bisa disebabkan karena konsep diri itu sendiri tidak hanya dipengaruhi oleh bullying tapi oleh banyak factor. Pola asuh serta perlakuan orang tua serta lingkungan turut memberikan pengaruh terhadap pembentukan konsep diri, berdasarkan hasil penelitian dari (Saraswati \& Sawitri, 2015). Menurut Saraswatia, et al, (2017) faktor - fakor yang mempengaruhi konsep diri remaja, bahwa ada beberapa hal yang mempengaruhi konsep diri remaja, yang pertama yaitu pola asuh orang tua, teman sebaya, dan penampilan fisik. Beberapa faktor ini menjadi alasan seseorang meskipun seseorang mengalami kejadian bullying tetapi konsep diri yang di miliki masih dalam kategori positif.

\section{KESIMPULAN}

Konsep Diri pada reemaja yang pernah mengalami bullying didapatkan bahwa jumlah yang mempunyai konsep diri positif dan negatif hampir seimbang, yaitu yang memiliki konsep diri positif sebanyak $45(51,1 \%)$ dan yang memiliki konsep diri negative sebanyak $43(48,9 \%)$.

\section{DAFTAR PUSTAKA}

Apriliyanti, A., Mudjiran, \& Ridha, M. (2016). hubungan konsep diri siswa dengan tingkah laku sosial siswa. Jurnal Pendidikan Indosesia, $2,2$.

Muawanah, lis binti. (2012). kematangan emosi, konsep diri dan kenakalan remaja. Jurnal Psikologi, 7, 1.

Potter \& Perry. (2010). Buku ajar keperawatan fundamental volume 1 Edisi 4.

Priyatna, A. (2010). lets end bullying : memahami, mencegah \& mengatasi bullying.

Rompas, A. E. T. R. K. S. (2018). Hubungan bullying dengan kepercayaan diri pada remaja di smp n 10 Manado. E-Journal Keperawatan.

Saraswati, M. A., \& Sawitri, D. R. (2015). konsep diri dengan kecenderungan bullying pada siswa kelas XI SMK. Jurnal Empati, 4, 60-65.

Saraswatia, gita kania, Zulpahiyana, \& Arifah, S. (2015). faktor - faktor yang mempengaruhi konsep diri remaja di SMP N 13 Yogyakarta. Journal Ners and 
Midwifery Indonesia, 3, 33-38.

Sarwono, Sarlito W (2013). Psikologi Remaja. Jakarta: Rajawali Pers

Sufriani, \& Sari, eva pyrnama. (2017). faktor yang mempengaruhi bullying pada anak usia sekolah di sekolah dasar Kecamatan Syiah Kuala Banda Aceh. Idea Nursin Journal, VII, 3.

Sumantri, B. (2011). Hubungan antara konsep diri dengan prestasi belajar pada mahasiswa pendidikan ekonomi STIKEP PGRI NGAWI, V111, 2.

Sunaryo (2013). Psikologi untuk Keperawatan Edisi 2. EGC. Jakarta

Stuart, G.W., and Sundenen, S.J. (2013). Buku saku keperawatan jiwa.6 thediton. St. Louis: Mosby Yeart Book.

Widiarti, P. W. (2017). konsep diri (self concept) dan komunikasi interpersonal dalam pendampingan pada siswa SMP se kota yogyakarta, $47,1$.

Zakiyah, Humaedi, Santoso. (2017). Faktor yang mempengaruhi remaja dalam melakukan bullying. Jurnal penelitian \& PPM , 4,2, 324-330 